\title{
AN ISOLATED POPULATION OF THE WHITE-CLAWED CRAYFISH (AUSTROPOTAMOBIUS PALLIPES) IN THE PRINCIPALITY OF LIECHTENSTEIN.
}

\author{
E. BOHL
}

Bavarian State Office for Water Resources Management, Institute for Water Research, Demollstraße 31, 82407 Wielenbach, Germany.

\begin{abstract}
An isolated stock of Austropotamobius pallipes is studied in a small water system draining into a tributary to the river Alpenrhein in the Principality of Liechtenstein. The population is known to originate from one single stocking activity of 109 specimens in 1985. Crayfish stock is investigated by direct observation at night and by trap catching including mark and recapture. Essential ecomorphological properties of the waters are recorded in respect to their attraction for crayfish. The stock is spread over two small natural ground water ponds and some connected ditches. The settled area is only 850 metres in total longitudinal extension and the boundaries of the stock are very sharp over only few metres on all sides following distinct changes of morphometry, structure or water flow which prevent the population from expanding. In addition, isolation from the downstream fauna is given by a local source of water pollution. The distribution of population density shows a heterogeneous micro-scale pattern corresponding to the distribution of structures and substrates in the waters. The population was estimated to at least 2.000 individuals. No subsidiary stocks were found in the ditch system. Parasitic growth of Branchiobdella pentodonta is very high and affects all individuals. Fish stock is confined to the species bullhead Cottus gobio, minnow Phoxinus phoxinus and brown trout Salmo trutta $f$. fario in low densities. Fish predation has no impact on the crayfish population. The waters are situated in a natural reserve, neither fish nor crayfish stocks are exploited by man. Stock situation and management are discussed.
\end{abstract}

Key-words : freshwater crayfish, Austropotamobius pallipes, stocking success, spatial distribution pattern, habitat structure, ecological impacts, parasites.

\section{UNE POPULATION ISOLÉE D'ÉCREVISSE AUX PIEDS BLANCS (AUSTROPOTAMOBIUS PALLIPES) EN PRINCIPAUTÉ DE LIECHTENSTEIN.}

\section{RÉSUMÉ}

On a étudié une population isolée d'Austropotamobius pallipes dans un petit système hydrographique, affluent du Rhin en principauté de Liechtenstein. La population est connue comme issue d'un stock de 109 animaux déversés une seule fois en 1985. Le peuplement est étudié par observation directe la nuit et par pêche à la nasse suivie d'une expérience de marquage et recapture. Des caractères essentiels de l'écomorphologie des 
eaux sont notés en fonction de l'attrait qu'ils semblent exercer sur les écrevisses. La population s'étend sur deux petits étangs naturels alimentés d'eaux souterraines et quelques fossés en communication. L'aire occupée s'étend sur $850 \mathrm{~m}$ et s'interrompt partout brusquement sur quelques mètres suivant des modifications de la morphométrie, de la structure et du courant qui empêchent la population de s'étendre. II y a, en outre, une isolation vers l'aval par une source ponctuelle de pollution d'eau. La densité de la population est aussi hétérogène que celle des structures et des substrats aquatiques qui l'hébergent. La population est estimée à moins de 2000 individus. II n'existe pas de populations secondaires dans le système hydrographique. Tous les animaux sont. fortement parasités par Branchiobdella pentodonta. Le peuplement piscicole est limité à trois espèces : le chabot, Cottus gobio, le vairon, Phoxinus phoxinus et la truite fario, Salmo trutta $f$. fario. Cet endroit est situé dans une réserve naturelle où ni les poissons ni les écrevisses ne sont exploités par l'homme. La situation et la gestion de cette population d'écrevisses sont discutées.

Mots-clés : écrevisses, Austropotamobius pallipes, succès de repeuplement, distribution spatiale, structure d'habitats, influences écologiques, parasites.

\section{INTRODUCTION}

Stocking activities with native crayfish are mostly restricted to commercial species as Astacus astacus and aim at establishing harvestable stocks in closed waters. Thus, the development of individual populations is mostly influenced by human activities. In other cases, the impact of stocking cannot be discerned clearly when knowledge about already present populations is lacking, due to the hidden life of the animals. Only very few experiences on the success of particular stocking efforts with non-commercial species as Austropotamobius pallipes in new or no-more settled areas are documented (FÜREDER and MACHINO, 1995). The expansion of the population in open drain systems and the distribution and habitat usage by populations under nature-like and uninfluenced conditions are mostly unknown. Populations of native crayfish species decline constantly in most parts of Europe suffering from different threats, while natural expansion and resettlement to suitable habitats are very low and not able to maintain the species at sufficient levels. Studies of the history of stocking experiments under conditions comparable to natural settlement are therefore very helpful for estimating the chances and to develop conceptions for protecting and restoring the species and their habitats.

The particular case of a defined and well-documented stocking act with Austropotamobius pallipes in a small drain system in the valley of river Alpenrhein is a good opportunity to study the expansion, population characteristics and habitat exploitation only few years later. The observations contribute to the knowledge about the local habitat and stock conditions for crayfish and can be used to develop guidelines for the protection and advancement of native crayfish species by the restoration of waters and an adapted fishery management.

Local names of waters («Krebsgraben») as well as historical notes indicate that natural crayfish stocks were existent in the territory of Liechtenstein until the last century, probably the species Astacus astacus and Austropotamobius torrentium. As far as known, these stocks died out when the crayfish plague reached the upper Rhine system in the years after 1880 (ALDERMAN, 1996). Since that time, very few and only sporadic findings of single crayfish of uncertain origin have been reported in the country, but no real crayfish populations. MARRER (1991) mentions only one stock of Astacus astacus which is known to have been established in 1980 by introducing animals by man. Austropotamobius torrentium must be regarded as extinguished. The crayfish stock of Aescher is the only population of Austropotamobius pallipes known in Liechtenstein. It was initiated by artificial stocking. 


\section{MATERIAL AND METHODS}

\section{The investigation area}

The meadows of Aescher are a small natural reserve area covering only about $0.5 \mathrm{~km}^{2}$ situated near the community of Planken in the northern part of Liechtenstein $\left(47^{\circ} 11^{\prime} 30^{\prime \prime} \mathrm{N}, 9^{\circ} 32^{\prime} 10^{\prime \prime} \mathrm{E}\right.$, altitude $445 \mathrm{~m}$ above sea-level). The drain system is very simple and consists of only two small and mostly parallel brooks joining outside the preservation area. Both have been artificially straightened completely. Scheidgraben, the southern ditch, is the outlet of two nature-like groundwater ponds which are connected to each other and fed by a small mountain rill. Schwabbrünner Graben, the northern branch of the system, comes directly from the mountain slopes. The geographic situation of the area and the distribution of the crayfish stock are sketched out in figure 1.

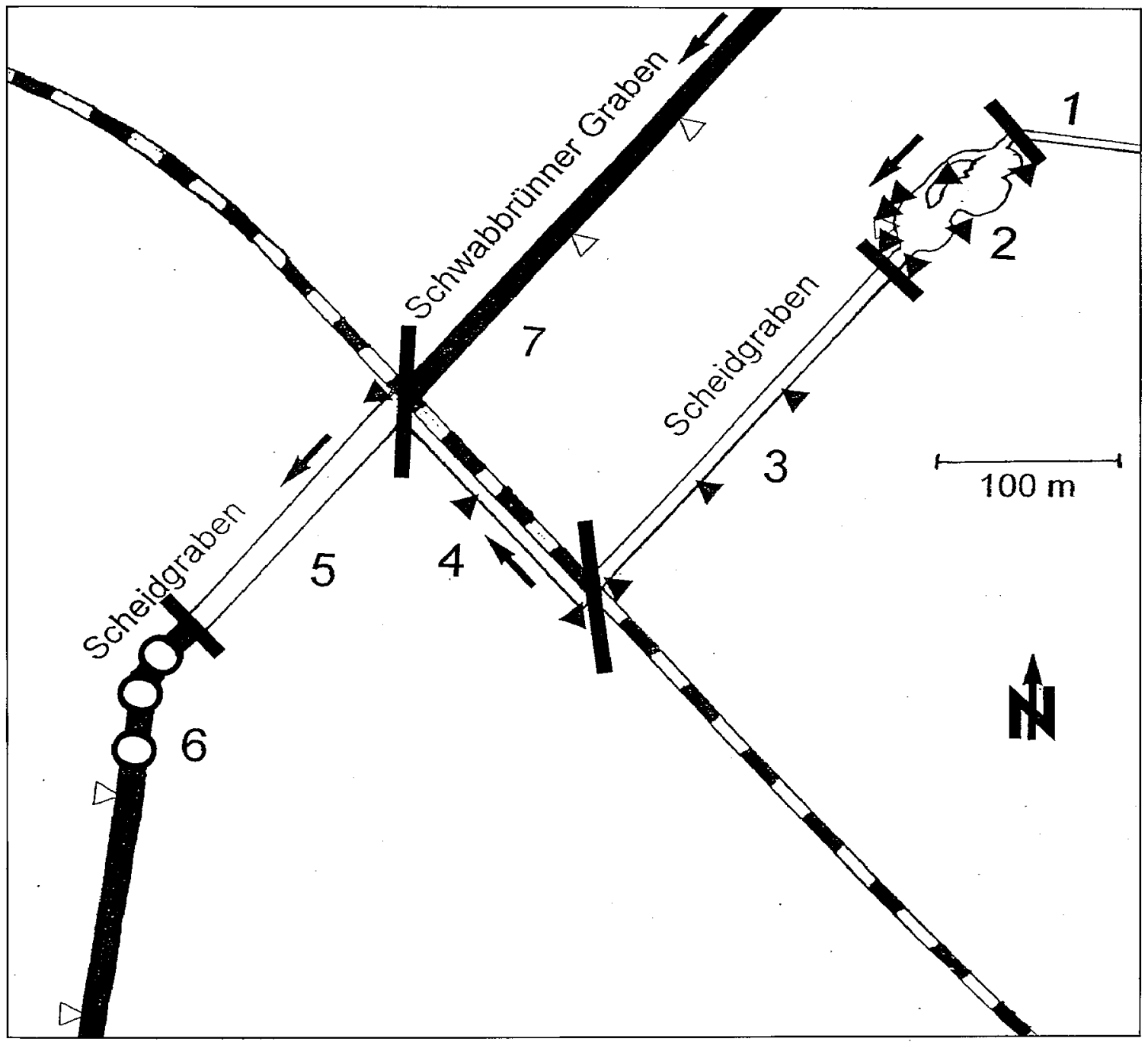

Figure 1

Map showing the investigation area (open ribbon : coherent crayfish stock; filled ribbon : sections without coherent crayfish stock; open circles : single crayfish findings ; triangles : positions of traps (filled : with catch ; open : without catch)).

Figure 1

Carte montrant la localisation des eaux examinées (ruban ouvert : stock d'écrevisses cohérent ; ruban plein : sections sans écrevisses ; cercles ouverts : écrevisses trouvées solitaires ; triangles : positions des nasses (plein : avec capture ; ouvert : sans capture)). 


\section{Methods of examination}

Experimental fishing was performed in October 1995 by searching the brooks at night with a strong torch and by means of crayfish traps. In order to record a wide range of size classes, two types of traps were used : basket traps made of plastic with the dimensions $64 \times 30 \times 26 \mathrm{~cm}$ (length $\times$ width $\times$ height), entrance width $8 \mathrm{~cm}$, mesh size $1.1 \mathrm{~cm}$, and small net traps of $40 \times 18 \times 18 \mathrm{~cm}$ (length $\times$ width $\mathrm{x}$ height), entrance width $4.5 \mathrm{~cm}$, mesh size $0.3 \mathrm{~cm}$. Both types had two horizontal entrances flush against the ground, one on each of the opposite sides. Freshly killed fish (roach) was used as bait. A . simple mark-and-recapture experiment was carried out to estimate roughly both density and size of the population. For this purpose, a number of captured crayfish were marked with a dot of nail polish on the carapace and released immediately at the place where they had been caught. A second trap effort was implemented the following night. Characteristics of the waters as for structure, substrates and vegetation were recorded, the fish stock was represented by electric fishing.

\section{RESULTS}

\section{Habitat}

Water samples were taken at the inflow and outlet of the ponds and at the end of section 5. Significant water parameters at the time of fishing are given in table I. The saprobial index of 1.8 (betamesosaprob) was determined by AMANN (1995).

Table I

Some values indicating the quality of the investigated waters (for positions of sample places, see figure 1).

\section{Tableau I}

Quelques valeurs significatives pour la qualité des eaux examinées (pour la localisation des lieux, voir figure 1).

\begin{tabular}{|l|c|c|c|}
\hline October 1st 1995 & influx (1) & outlet (2/3) & boundary (5/6) \\
\hline temperature $\left({ }^{\circ} \mathrm{C}\right)$ & 8,7 & 11,8 & 12,2 \\
\hline $\mathrm{pH}$ & 7,1 & 7,3 & 7,6 \\
\hline conductivity $(\mu \mathrm{S} / \mathrm{l})$ & 403,0 & 412,0 & 415,0 \\
\hline acid capacity $(\mathrm{mmol} / \mathrm{l})$ & 3,2 & 3,2 & 3,5 \\
\hline oxygen concentration $(\mathrm{mg} / \mathrm{l})$ & 11,2 & 10,6 & 10,2 \\
\hline
\end{tabular}

Whenever Scheidgraben and its tributary have been regulated and straightened completely except for two sharp bends in the past, the structural conditions vary remarkably along the brook mainly as a consequence of vegetation and construction. At least seven different sections were to discern :

1. small turbulent creek from the mountains feeding the ponds ( $30 \mathrm{~m}$ length) ;

2. ponds ( $150 \mathrm{~m}$ length) : the ponds are of irregular shape, the shores have variable slopes, submerse vegetation is partially dense; 
3. from pond outlet to railway embankment ( $260 \mathrm{~m}$ length) : the upper course of Scheidgraben from the ponds downstream to an underpass through the railway embankment is mostly shaded by trees and bushes. Fallen leaves, driftwood and roots are abundant preserving diversity of structure and flow. Hides are available. Submerse vegetation is sparse. Clay, sand, and gravel are dominant substrates. Maximum depths vary slightly from 15 to $20 \mathrm{~cm}$, in only one place to $40 \mathrm{~cm}$. The cross-section is shaped irregular showing alternating undermines, steeps and flat banks ;

4. along the railway embankment (160 $\mathrm{m}$ length) : after passing the railway embankment, the brook turns in a sharp bend and enters an open meadow. The surface is almost completely covered with dense Veronica beccabunga vegetation. In its roots, muddy sediment is deposited in layers of more than $20 \mathrm{~cm}$ of thickness closing the bottom totally;

5. section of rotten bank and soil reinforcement (140 m length) : after taking in the tributary Schwabbrünner Graben, the brook turns again in a sharp bend into a straight course with completely timbered bottom and stony bank borders. The reinforcements are partially rotten and full of gaps ;

6. muddy section (500 m length) : before a slight bend, flow velocity declines and muddy sediments cover all gaps in the bottom and bank constructions ;

7. Schwabbrünner Graben (400 m length) : a small, shallow and straight tributary which is barely structured and which falls dry temporarily.

Further characteristics of the particular sections are summarised in table II.

Table II

Physical characteristics of the examined sections of the waters (for positions, see figure 1).

Tableau II

Caractéristiques physiques des sections des eaux (pour les localisations, voir figure 1).

\begin{tabular}{|c|c|c|c|c|c|c|c|}
\hline section & $\begin{array}{c}\text { maximum } \\
\text { depth } \\
(\mathbf{c m})\end{array}$ & $\begin{array}{c}\text { mean } \\
\text { width } \\
(\mathbf{m})\end{array}$ & $\begin{array}{c}\text { dominant } \\
\text { substrates }\end{array}$ & $\%$ shade & $\begin{array}{c}\text { structural } \\
\text { diversity }\end{array}$ & $\begin{array}{c}\text { max. flow } \\
\text { velocity } \\
\mathbf{( c m / s )}\end{array}$ & $\begin{array}{c}\text { submerse } \\
\text { vegetation }\end{array}$ \\
\hline 1 & 5 & 0.5 & stones & 40 & +++ & 30 & - \\
\hline 2 & $>200$ & $>8$ & clay, mud & $<5$ & ++ & 0 & ++ \\
\hline 3 & 40 & 0.7 & clay, sand & 80 & ++ & 15 & + \\
\hline 4 & 30 & 0.8 & mud & 10 & + & 5 & +++ \\
\hline 5 & 15 & 1.0 & planks & 0 & ++ & 25 & - \\
\hline 6 & 15 & 1.0 & mud & 0 & - & 15 & + \\
\hline 7 & 5 & 0.4 & clay & 20 & + & 10 & - \\
\hline
\end{tabular}




\section{Crayfish stock}

In May 1995, the presence of a population of white-clawed crayfish was already verified qualitatively by trap catches of males and females, most of them in berry. On October 1st, one night's total catch success in 13 traps was 173 crayfish (1 to 28 individuals per trap), 5 traps remained empty (for localisation of traps, see figure 1). In addition, direct observation by searching all sections $(1-7)$ detected 32 crayfish and further 16 predominantly smaller ones escaping from the light beam. Samples from the trap catches were measured, marked and released at their respective place. Traps were exposed the following night in the same places. The results of the recapture experiment are shown in table III. Accepting very rough and simplifying assumptions as total mixing, equal catchability of all crayfish and no impact of the marking procedure as well as neglecting moulting, mortality and emigration - immigration, population numbers $(\mathrm{N})$ can approximately be estimated for each section from the index :

$$
N=n \times a / r
$$

where $n=$ total number of second catch, $a=$ total number of marked and $r=$ total recapture of marked animals in the section. From these values, densities are calculated in individuals per $100 \mathrm{~m}$ of watercourse (table III).

Table III

Results of a mark-and-recapture experiment for the estimate of individual numbers ( $n$ ) and densities of the crayfish population for each section.

Tableau III

Résultats d'une expérience de marquage et recapture pour estimer le nombre (n) et la densité de la population d'écrevisses pour chaque section.

\begin{tabular}{|c|c|c|c|c|c|c|c|}
\hline section & $\begin{array}{c}\text { length } \\
(\mathbf{m})\end{array}$ & $\begin{array}{c}\text { 1st catch }+ \\
\text { observation }\end{array}$ & $\begin{array}{c}\text { marked and } \\
\text { released }\end{array}$ & $\begin{array}{c}\text { 2nd catch } \\
\mathbf{n} \text { total }\end{array}$ & $\begin{array}{c}\text { recaptures } \\
\mathbf{n} \text { marked }\end{array}$ & $\begin{array}{c}\text { estimate } \\
\mathbf{n}\end{array}$ & $\begin{array}{c}\text { density } \\
(\mathbf{n} / \mathbf{1 0 0 m})\end{array}$ \\
\hline 1 & 30 & 0 & 0 & 0 & 0 & 0 & 0,0 \\
\hline 2 & 150 & 52 & 44 & 55 & 3 & 807 & 537,8 \\
\hline 3 & 260 & 113 & 94 & 98 & 15 & 614 & 236,2 \\
\hline 4 & 160 & 44 & 31 & 29 & 5 & 180 & 112,4 \\
\hline 5 & 200 & 9 & 4 & 8 & 1 & 32 & 16,0 \\
\hline 6 & 500 & 3 & 1 & 4 & 1 & 4 & 0,8 \\
\hline 7 & 400 & 0 & 0 & 0 & 0 & 0 & 0,0 \\
\hline sums & 1700 & 221 & 174 & 194 & 25 & 1637 & \\
\hline
\end{tabular}

A coherent crayfish stock was found over a total longitudinal extension of 850 metres including sections $2-5$ as well as the bypass ditch beneath the ponds. The boundary of the settled area was very sharp between sections 5 and 6 and followed strictly the change to muddy substrate covering the gaps of bottom and banks. Outside this range, only three single large males were found. For the settled area, a total number of 
1.637 individuals was estimated from the catches, which of course, as a result of only one experiment, can only give the order of magnitude. In addition, the sedentary behaviour of crayfish individuals accustomed to their particular place, which is known from earlier studies, leads to a higher ratio of recatches and consequently to a lower estimation of the population number. Young crayfish (age classes $0+$ and $1+$ ) are usually under-represented both in trap catches and direct observations as well (BOHL, 1989 a), also in this case the catch of young crayfish was very low. To record the number of young crayfish requires particular methods. Thus, the estimate must be confined mainly to the mature age classes and can only roughly quantify the population to at least 2.000 mature animals.

Local densities were very variable ranging from about 0.5 individual to more than 500 individuals per $100 \mathrm{~m}$ shoreline within the stock. This heterogeneous distribution of animals corresponds to the availableness of structures and substrates of different quality. A number of particular habitats could be identified to attract crayfish :

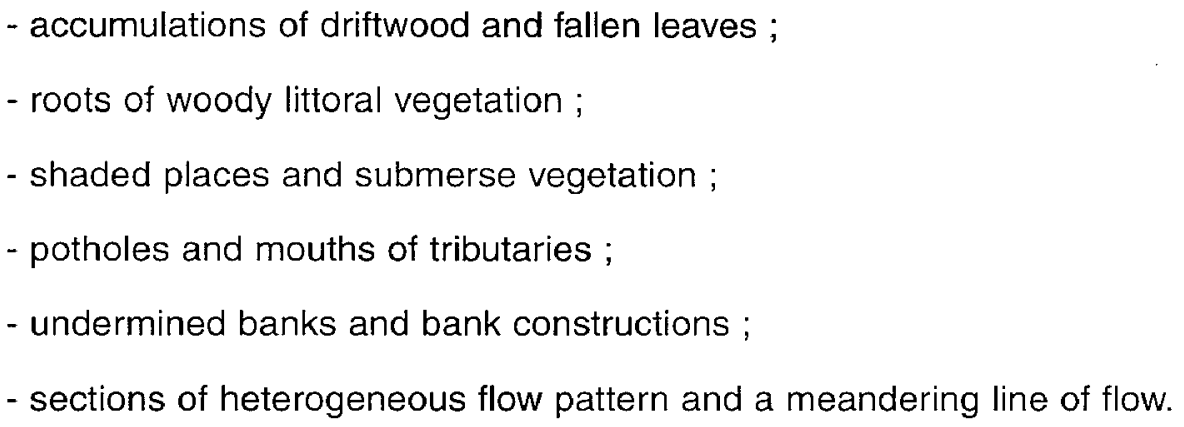

In general, hard bottom substrates as gravel, sand and clay were preferred to soft, muddy and algae-covered ones. Extended shallows and sunny places without hides and vegetation were avoided as well as stretches of regular geometric cross-cut.

Age cannot be determined decidedly in single living crayfish but the lengthfrequency distribution of a sample can represent the distribution of the age groups in a population. Figure 2 shows the results from the trap catch (lengths are given as the distance from the rostrum tip to the back edge of the telson). As a consequence of low catchability, young age classes are underrepresented. However, the wide range of length classes, the occurrence of egg-bearing females in the springtime investigation and the expansion of the population since the initial stocking act prove successful natural reproduction. Sexes were distributed $63 \%$ males to $37 \%$ females in the sample. This must not be taken as the real sex ratio in the population, for several reasons. Adult female crayfish have a characteristic cycle of activity over the seasons showing an activity level comparable to the males, only from late summer until the mating season in autumn (BOHL, 1989 a). During the rest of the year, above all during the time they carry eggs, females prefer to stay in their hides and thus are not to be seen or caught in traps. The time of the experimental catch was already near to the end of the active phase. Above that, it has been shown in pond experiments that females as well as small crayfish avoid to enter traps which are already occupied by large numbers of males (BOHL, 1992). So, the sex ratios obtained in the catches are in accordance with observations in other crayfish populations under similar conditions, where a balanced relation of sexes was proved by further investigations. 


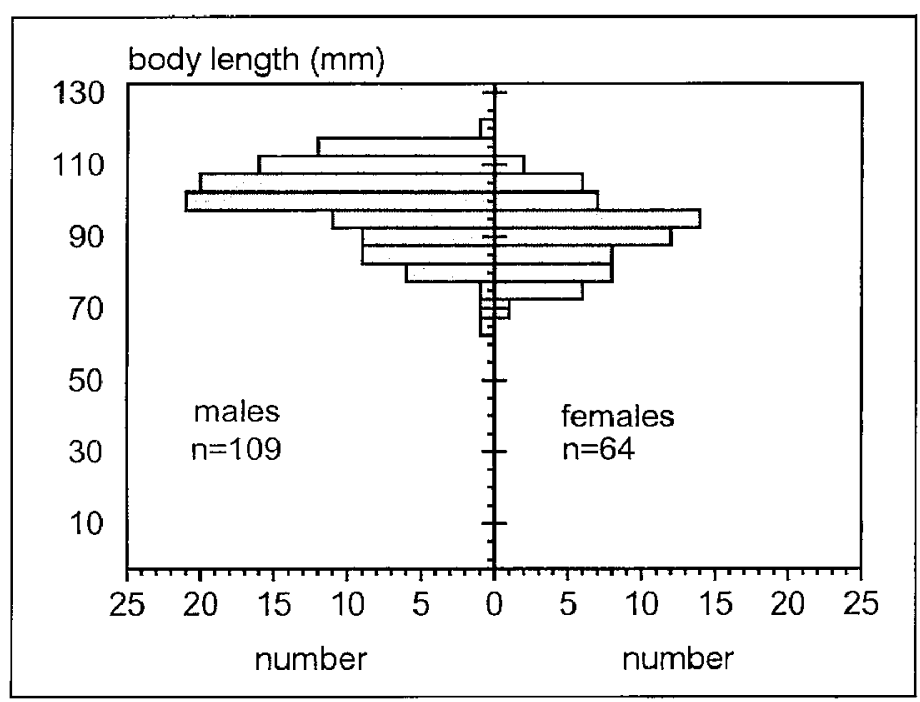

Figure 2

Length distribution of crayfish from the trap catches (rostrum tip to rear edge of telson).

Figure 2

Distribution de tailles des écrevisses attrapées dans les nasses (pointe du rostrum jusqu'au bord arrière du telson).

All collected and trapped crayfish were very lively and showed good reactions. A wide scattering of shell colours implied a sufficient genetic variability in spite of the relatively low number of individuals in the initial population. The portion of damaged crayfish in a population can indicate the risk of violation by predators. In the catch samples, only $22 \%$ of all animals showed injuries which were located predominantly at claws and legs (figure 3 ). Most of them could be recognised rather to be affected by moulting than by external violation.

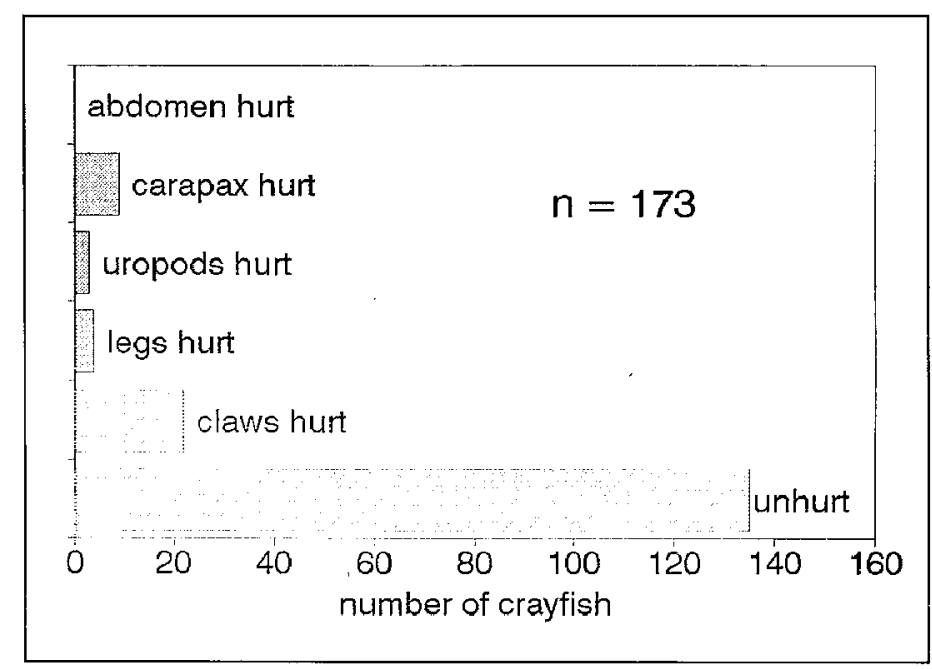

Figure 3

Frequency distribution of damages to the parts of the bodies in crayfish from the trap catches.

\section{Figure 3}

Distribution de fréquences des blessures sur les parties du corps des écrevisses attrapées dans les nasses. 
Fish species in the brook system were minnow (Phoxinus phoxinus), bullhead (Cottus gobio) and brown trout (Salmo trutta $f$. fario) in low densities. The total catch was 62 minnows, 22 bullheads and 30 trout over $850 \mathrm{~m}$ of watercourse. In the length distribution of brown trout, for example (figure 4), large individuals are not abundant so that predation by fish can be excluded as a threat to the crayfish population. Upstream migration of other predatory fish from outside to the crayfish area is prevented by a stretch of water polluted with $\mathrm{H}_{2} \mathrm{~S}$ from a pump station in the lower part of Scheidgraben.

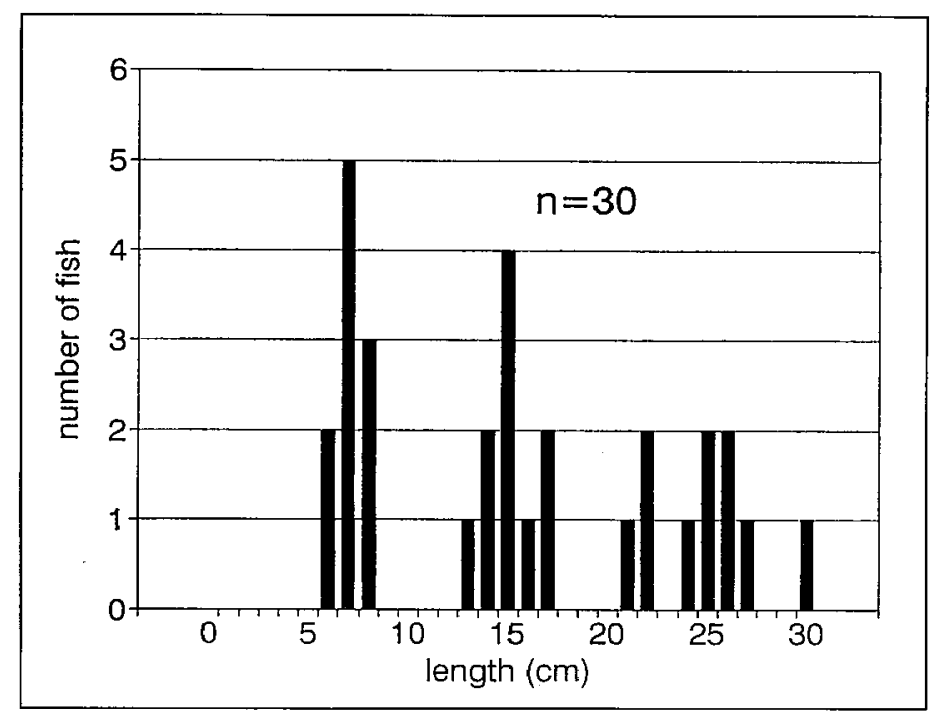

Figure 4

Length distribution of brown trout in the crayfish area from electric fishing.

Figure 4

Distribution de tailles des truites pêchées au moyen de l'électricité dans les sections colonisées par des écrevisses.

All examined crayfish were affected by a clitellat worm which was identified according to NESEMANN (1994) as Branchiobdella pentodonta. This parasitic growth was already reported from the stocked crayfish in 1985. Branchiobdella species are found on most free living crayfish populations, $B$. pentodonta is described rather to be a commensal than a real parasite, so harm to crayfish seems not to be serious, even if densities of more than 400 individuals per crayfish were observed in the Scheidgraben population. External symptoms of diseases, e.g. the porcelain disease caused by Thelohania contejani, could not be diagnosed.

\section{DISCUSSION}

The occurrence of the white-clawed crayfish in Liechtenstein in historical time is not proved. However, the upper Rhine valley belongs to its phylogenetic distribution area (ALBRECHT, 1983) and is not too far away from recent natural populations (TROSCHEL and DEHUS, 1993 ; HOLDICH, 1995). So, Austropotamobius pallipes might be regarded as a potentially native species.

The investigation was focused more on a qualitative study of stock and habitat than on a quantitative analysis. So, the estimation can only approximately indicate the population number. Regarding the state both of the population and of the individuals in the 
Aescher stock, there is no reason to suppose conditions of age structure completely different from other comparable white-clawed crayfish populations (GRANDJEAN et al., 1997). Consequently, a much higher number of young individuals has to be assumed.

The white-clawed crayfish population of Aescher originates from the stocking of 109 crayfish of both sexes and various age classes in 1985. The growth of the population to more than estimated 2.000 mature and probably just as many young individuals within ten years is a good but certainly not an extraordinary colonisation success for crayfish in a natural water. Population density and the ratio of sexes should allow a high mating frequency and realise a reproductive capacity which should be more than sufficient to maintain the stock. Natural spreading of the population over a wider area, however, fails for want of spatial continuity of suitable habitats.

The Aescher brooks are a system of originally straightened and functional ditches which surely do not offer optimal structural conditions for crayfish. However, already the omission of upkeeping measures in the last years allowed a minimum of nature-like structures to develop and crayfish to establish. The high degree of dependency of crayfish from structures is typically documented by the distribution of individuals and by sharp boundaries of the distribution of animals corresponding to the change of structural characters within the waters (LAURENT, 1985 ; BOHL, 1989 a). In lower stretches of Scheidgraben, only occasional single crayfish were found at times during the last years. Factors that prevent the Aescher population from expanding can be identified as low discharge, rapid flow and low temperature (section 1, influx of the pond), small dimension and lack of structure (section 7, Schwabbrünner Graben) and, finally, muddy substrate and lack of cover (section 6, lower part of Scheidgraben). Both, from these observations and from the examination of the favourite habitats of crayfish, the minimum requirements to the structure of the environment can be derived. Similar to the species Astacus astacus and Austropotamobius torrentium, more the morphometric and structural diversity per se is an essential precondition for the persistence of the species than the availability of particular special elements (BOHL, $1989 \mathrm{~b}$ ).

The distribution of the crayfish population to the ponds and to the brook in the same time lowers the risk of extinction in cases of dryness or freeze. In addition, the constancy of discharge provides sufficient living space in the brook although it amounts to only few $1 / \mathrm{s}$, and deeper pools in the ditch are scarce.

\section{CONCLUSION}

Native crayfish populations in Europe are mostly restricted to upper courses of the drain systems and to isolated waters by impacts of water pollution, water construction, fish predation and by the crayfish plague. These remote populations in general suffer from a high risk of extinction because of mostly small numbers of individuals, small extension, high degree of isolation and unstable environmental conditions. Restraints are still too grave and natural expansion of crayfish is too low to regain former habitats. Thus, viable populations adapted to the particular local conditions of climate and waters are indispensable genetic pools for the region. The protection of these population reserves is therefore of high priority. Regarding its relatively low number of individuals and its small extension, an exploitation of the Aescher crayfish stock for commercial or recreational fishing would not be in accordance with the aim to protect and develop the species. Fishing should be restricted to local authorities and only occasionally performed in order to gain material for new stock foundations. 
The example documents that even in an agricultural environment small-scale protection measures can contribute to the restoration of ecological functionality of waters. The Aescher crayfish stock should encourage to continue and to expand the improvements of environmental conditions for crayfish. Effective conceptions, however, must include sufficient water quality and discharge as well as the preservation and development of structural and hydraulic diversity. This requires protective strips of land along the watercourses which are kept out of agricultural exploitation to enable an adapted littoral vegetation to grow and natural dynamics of flow erase the banks and move materials.

In view of the great risk of bringing in the crayfish plague fungus together with animals from outside or foreign species (HOLDICH, 1989), all measures suitable to develop already established populations of fish and crayfish should have clear superiority over artificial stocking. In addition, stocking efforts must fail, if the waters do not comply with the specific requirements of crayfish. These requirements to water and stock management can be taken as exemplary because they relate to all native crayfish species in Europe basically.

\section{ACKNOWLEDGEMENTS}

Mr. Theo KINDLE (Liechtenstein State Office for Water Protection) kindly contributed to many important informations and active assistance.

\section{REFERENCES}

ALBRECHT H., 1983. Besiedlungsgeschichte und ursprüngliche holozäne Verbreitung der europäischen Flußkrebse (Decapoda, Astacidae). Spixiana, 6, 61-77.

ALDERMAN D.J., 1996. Geographical spread of bacterial and fungal diseases of crustaceans. Rev. sci. tech. Off. int. Epiz., 15 (2), 603-632.

AMANN E., 1995. Report on biological investigations at Scheidgraben, unpublished.

BOHL E., 1989 a. Ökologische Untersuchungen zur Entwicklung von Zielvorstellungen des Gewässerschutzes. Untersuchungen an Flußkrebsbeständen. Berichte der Bayerischen Landesanstalt für Wasserforschung, $237 \mathrm{p}$.

BOHL E., 1989 b. Comparative studies on crayfish brooks in Bavaria (Astacus astacus L. and Austropotamobius torrentium Schr.). Freshwater Crayfish, 7, 287-294.

BOHL E., 1992. Bewertung von Krebsbeständen bei Gewässerschäden in natürlichen Gewässern ; methodische Ansätze, Grundlagen. Wertermittlungsforum H.2, 83-87.

FÜREDER L., MACHINO Y., 1995. Record of the white-clawed crayfish Austropotamobius pallipes (Lereboullet, 1858) from Plansee (Tyrol, Austria). Ber. nat.-med. Verein Innsbruck, Vol. 82, 241-246.

GRANDJEAN F., ROMAIN D., SOUTY-GROSSET C., MOCQUARD J.P., 1997. Size at sexual maturity and morphometric variability in three populations of Austropotamobius pallipes pallipes, Lereboullet according to a restocking strategy. Crustaceana, 70(4), 454-468.

HOLDICH D.M., 1989. The dangers of introducing alien animals with particular reference to crayfish. Freshwater Crayfish, 7, 15-30.

HOLDICH D.M., 1995. Austropotamobius pallipes (Lereboullet, 1858). In : Background information on invertebrates of the Habitats Directive and the Bern Convention (VAN HELSINGEN P.J., WILLEMSE L. and SPEIGHT M.C.D. (eds.), Nature and environment No. 79, 1-7. 
LAURENT P.J., 1985. Une station d'écrevisses à pieds blancs Austropotamobius pallipes Lere. (Decapoda - Astacidae) en zone périurbaine. Bull. de la Soc. Linnéenne de Lyon, 54. Jg., Nr. 3, 77-88.

MARRER H., 1991. Fischereibiologisches Sanierungs- und Bewirtschaftungskonzept für die liechtensteinischen Fliessgewässer. Expertise by order of the Principality of Liechtenstein, State Office for Water Protection, 54 p., with appendix.

NESEMANN H., 1994. Die Krebsegel im Gebiet der oberen Donau (Österreich, Deutschland) mit Bestimmungsschlüssel zu den europäischen Arten (Clitellata, Branchiobdellida). Lauterbornia, Heft 19, 79-93.

TROSCHEL H.J., DEHUS P., 1993. Distribution of crayfish species in the Federal Republic of Germany, with special reference to Austropotamobius pallipes. Freshwater Crayfish, 9, 390-398. 